\title{
1. INTRODUCTION TO LOGGING-WHILE-DRILLING INVESTIGATIONS OF FAULTING, FLUID FLOW, AND SEISMIC IMAGES OF THE NORTHERN BARBADOS SUBDUCTION ZONE ${ }^{1}$
}

\author{
Shipboard Scientific Party ${ }^{2}$
}

\begin{abstract}
Deformation and fluid flow in sedimentary sequences alter physical properties. In situ measurements of physical properties evaluate diagenetic and structural processes (consolidation, cementation, and dilation) operating during deformation, fluid flow, and faulting. Because seismic images are affected by changes in physical properties, the measurement of physical properties allows the calibration of seismic data as a tool for remotely sensing evidence of deformation and fluid flow. Logging while drilling (LWD) can evaluate physical processes in situ, including transient borehole conditions. During Ocean Drilling Program Leg 171A, a series of LWD holes was drilled to measure physical properties through the Barbados accretionary prism. Extensive previous coring and a three-dimensional seismic survey provide a rich framework for log interpretation, seismic calibration, and evaluation of active diagenetic and structural processes. The results will assist interpretation of similar but less active systems in sedimentary basins elsewhere, contributing to the analysis of groundwater flow, hydrocarbon migration, and earthquake processes.
\end{abstract}

\section{INTRODUCTION}

Fluids influence fault behavior. Leg 171A focused on the role of fluids in deformation along the subduction megathrust between the North American and Caribbean Plates (Fig. 1). Faulting and deformation in accretionary prisms involve changing physical properties that produce fluid, control fluid flow, alter rheologic properties, and affect seismic velocities and reflection characteristics. Physical properties, specifically porosity, permeability, density, and sonic velocity, change through consolidation and chemical diagenesis. These alterations are both distributed, because of the loss of fluids in response to accumulating stresses (Bray and Karig, 1986; Bangs et al., 1990), and localized along faults, in response to overpressuring, fluid migration, mineral precipitation, lithologic juxtaposition, or fault collapse (Shipley et al., 1994; Tobin et al., 1994; Bangs et al., 1996). Modifications of physical properties associated with consolidation, fluid overpressuring, and faulting directly affect seismic reflections; therefore, seismic data provide a direct method to remotely sense changes in physical properties coupled to deformation.

Physical properties evolution in sedimentary sequences, including accretionary prisms, cannot be comprehensively evaluated with recovered cores and must be studied in situ. Elastic rebound and microcracking of coherent sedimentary samples degrade laboratory physical properties measurements. Fault gouge and other incoherent lithologies either are not recovered or cannot be measured after recovery. Transient properties (e.g., excess pore pressure) must be measured in situ (Fisher et al., 1996; Becker et al., 1997). Logging while drilling (LWD) is the best available tool for measuring physical properties of the typically underconsolidated prism sediments; LWD results can be used as input to time-transient models of prism evolution.

Large strains at subduction zones accelerate the rate of change in physical properties of sedimentary sequences accumulating and deforming there. Accretionary prisms allow these changes to be studied because deformational features are shallowly buried and shallowly dipping and therefore can be cored and imaged seismically. Studies of fault geology, sedimentary consolidation, and seismic imaging at subduction zones aid our understanding of hydrocarbon migration,

'Moore, J.C., Klaus, A., et al., 1998. Proc. ODP, Init. Repts., 171A: College Station, TX (Ocean Drilling Program).

${ }^{2}$ Shipboard Scientific Party is given in the list preceding the Table of Contents. groundwater flow, and seismicity in similar, but less active, sedimentary environments. We conducted an LWD transect of the northern Barbados accretionary prism to better elucidate the interrelationships of deformation, fluid flow, seismic imaging, and changes in physical properties (Figs. 2, 3; also see Fig. 2 in the "Site 1044" chapter, backpocket foldout, this volume).

\section{TECTONIC SETTING OF THE NORTHERN BARBADOS ACCRETIONARY PRISM}

The northern Barbados accretionary prism is the leading edge of the Caribbean Plate that is being underthrust by the Atlantic Ocean floor at rates estimated between 20 and $40 \mathrm{~km} / \mathrm{m}$.y. (Dorel, 1981; Jordan, 1975; Sykes et al., 1982; DeMets, 1990). The Lesser Antilles to the west defines the volcanic arc, and the island of Barbados, east of the arc, is an outcrop of the forearc accretionary prism. Frontal structures south of Tiburon Rise include long-wavelength folds, widely spaced ramping thrust faults, and extensive décollement reflections (e.g., Bangs and Westbrook, 1991; Westbrook and Smith, 1983). On and north of Tiburon Rise, the trench sediment thickness is much thinner and prism thrusts are more closely spaced (Biju-Duval et al., 1982; Westbrook et al., 1984). The Barbados accretionary prism is at least $10 \mathrm{~km}$ thick and $120 \mathrm{~km}$ wide north of the rise, and a 50-kmwide forearc basin lies to the west (Bangs et al., 1990; Westbrook et al., 1988). Thus, the accretionary prism forms a wide, tapering wedge.

Deep Sea Drilling Project (DSDP) Leg 78A and Ocean Drilling Program (ODP) Legs 110, 156, and 171A all focused on the northern flank of Tiburon Rise. Here, the décollement zone is relatively shallow and the dominantly hemipelagic-pelagic sedimentary section offers good drilling conditions and good biostratigraphic resolution. In this area, previous drilling results document numerous biostratigraphically defined faults, of mostly thrust displacement (Brown and Behrmann, 1990). The décollement zone becomes better defined landward and is a shear zone as much as 40 m thick at Sites 671 and 948 (Mascle, Moore, et al., 1988; Shipley, Ogawa, Blum, et al., 1995). Anomalies in pore-water chemistry (Gieskes et al., 1990; Kastner et al., 1997) and temperature (Fisher and Hounslow, 1990) indicate focused fluid flow along fault zones and in sand layers. Models simulating this fluid expulsion from the prism suggest that the flow is transient (Bekins et al., 1995). The faults are characterized by 


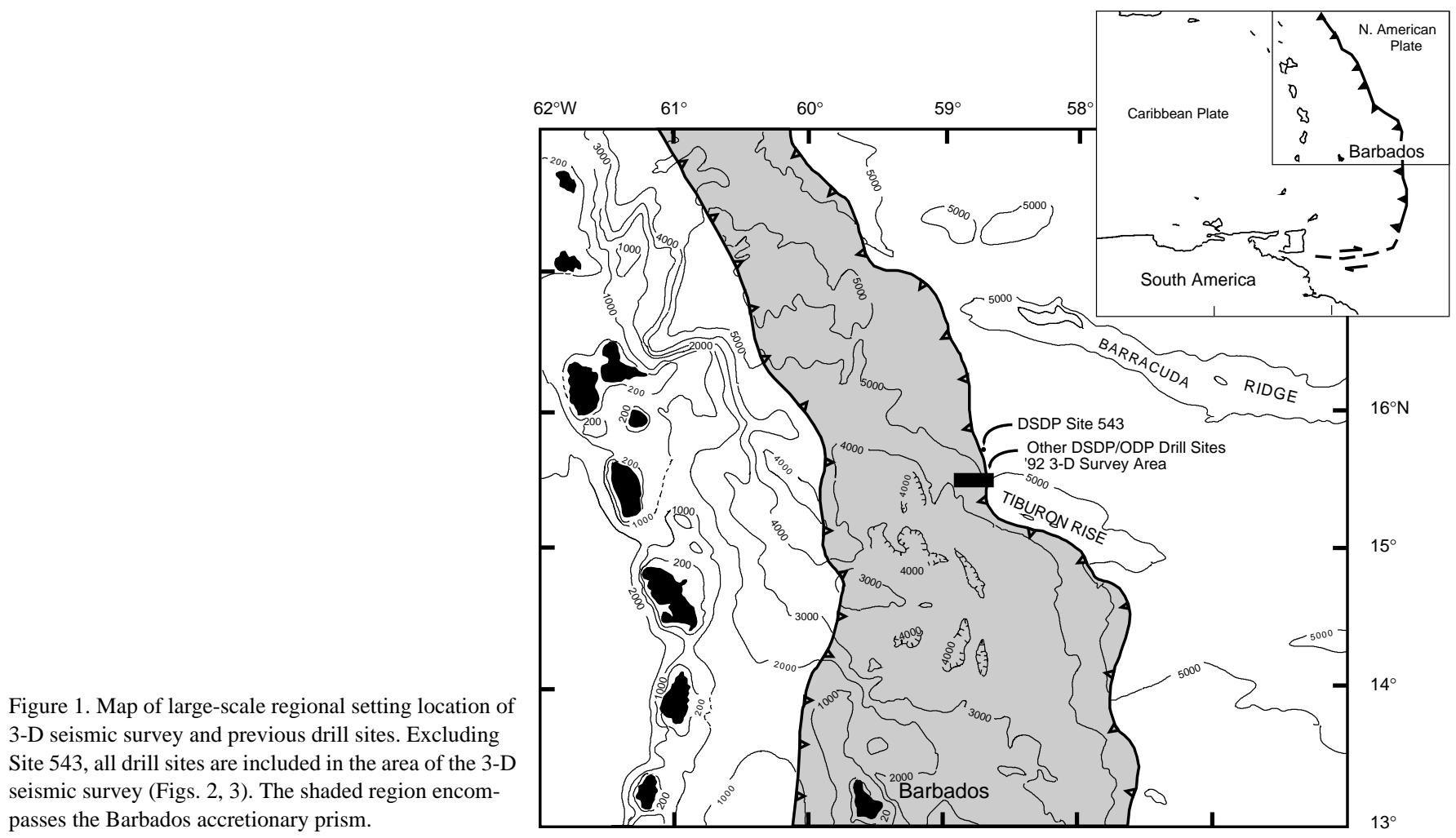

suprahydrostatic, and locally nearly lithostatic, fluid pressures (Brückmann et al., 1997; Labaume et al., 1997; Screaton et al., 1997; Zwart et al., 1997).

A 3-D seismic reflection survey (Shipley et al., 1994; Moore et al., 1995a) has greatly improved the interpretation of drilling results from the northern Barbados accretionary prism (Figs. 2B, 3, 4). In addition to better defining the stratigraphy and structure, the seismic survey also outlines patches of positive and negative seismic polarity on the décollement zone. These polarity signatures may signify differing fluid regimes and stress states along the décollement zone (Shipley et al., 1994; Bangs et al., 1996; Tobin and Moore, 1997; Shipley et al., 1997). Determining the physical properties that define these polarity signatures is a major goal of Leg 171A.

\section{LOGGING WHILE DRILLING}

LWD is the most effective tool for measuring physical properties in poorly consolidated sediments, where standard wireline systems previously acquired either no data or poor-quality data. LWD provides measurements from the waterline to the deepest level of bottom-hole assembly (BHA) penetration. LWD acquires a continuous $\log$ of physical properties from directly above the drill bit, where hole conditions are optimal for logging. LWD measures the properties of the formation minutes after cutting the hole, thereby closely approximating in situ conditions.

\section{Scientific Objectives of Leg 171A}

1. Overall prism consolidation: Porosity distribution is the foundation for a variety of studies of the large-scale, long-term fluid budget of accretionary prisms. Logs can be used to determine a continuous record of density and porosity as a function of depth, as was done at Leg 156 Sites 947 and 948. Between-site variation in the porositydepth relationship provides an estimate of the amount of fluid expulsion (and, therefore, volumetric strain). Unfortunately, in accretion- ary prisms these measurements of volume change are usually impossible to obtain with standard logs, which usually fail as a result of the typically unstable hole conditions. Even under ideal conditions, wireline logs do not obtain data from the top 60-120 $\mathrm{m}$ (because the drill pipe extends below the seafloor) or from the bottom $60-120 \mathrm{~m}$ of the hole (because of fill). The first $100 \mathrm{~m}$ is of particular interest in volumetric studies because this is where porosity reduction is the greatest. Only LWD can obtain reliable porosity $\operatorname{logs}$ from the entire depth range. The overall fluid budget of the northern Barbados accretionary prism requires modeling to evaluate the fluid loss and geochemical budgets (e.g., Bekins et al., 1995). Observations of prism consolidation critically constrain these models. The series of LWD holes planned for Leg 171A, plus the existing penetrations and seismic reflection results, provides these essential data.

2. Correlation of physical properties of faults with displacement and fluid flow: Do faults collapse and strain harden with displacement (e.g., Karig, 1986)? Does active fluid flow retard this process, and are collapsed faults inactive with respect to fluid flow (e.g., Brown et al., 1994)? Can hydrofractures be observed in the Barbados décollement zone? Can faults act as hydrologic conduits with variable and transient properties, as required by the models of Bekins et al. (1995)? The Leg 171A LWD transect across the Barbados décollement zone addresses these questions. Information from cores and seismic reflection data locates faults. Once the faults are positively identified, LWD can measure their physical properties, which can then be correlated to variations in displacement and fluid activity.

3. Consolidation state of sediments in and around faults: At Site 948, high-quality density measurements demonstrate underconsolidation beneath thrust faults, indicating that the hanging wall of the faults recently loaded subjacent sediments. The consolidation state can also be interpreted in terms of effective stress and fluid pressure. Clearly, the consolidation varies around faults and must be defined to develop a tectono-hydrologic model of the fluid expulsion system.

4. Physical characteristics of negative polarity seismic reflections from fault zones: Seismic reflections are created by changes in physical properties that can be measured in boreholes. In principle, the 
A

$58^{\circ} 46^{\prime} \mathrm{W}$

$58^{\circ} 42^{\prime}$ $58^{\circ} 40^{\prime}$
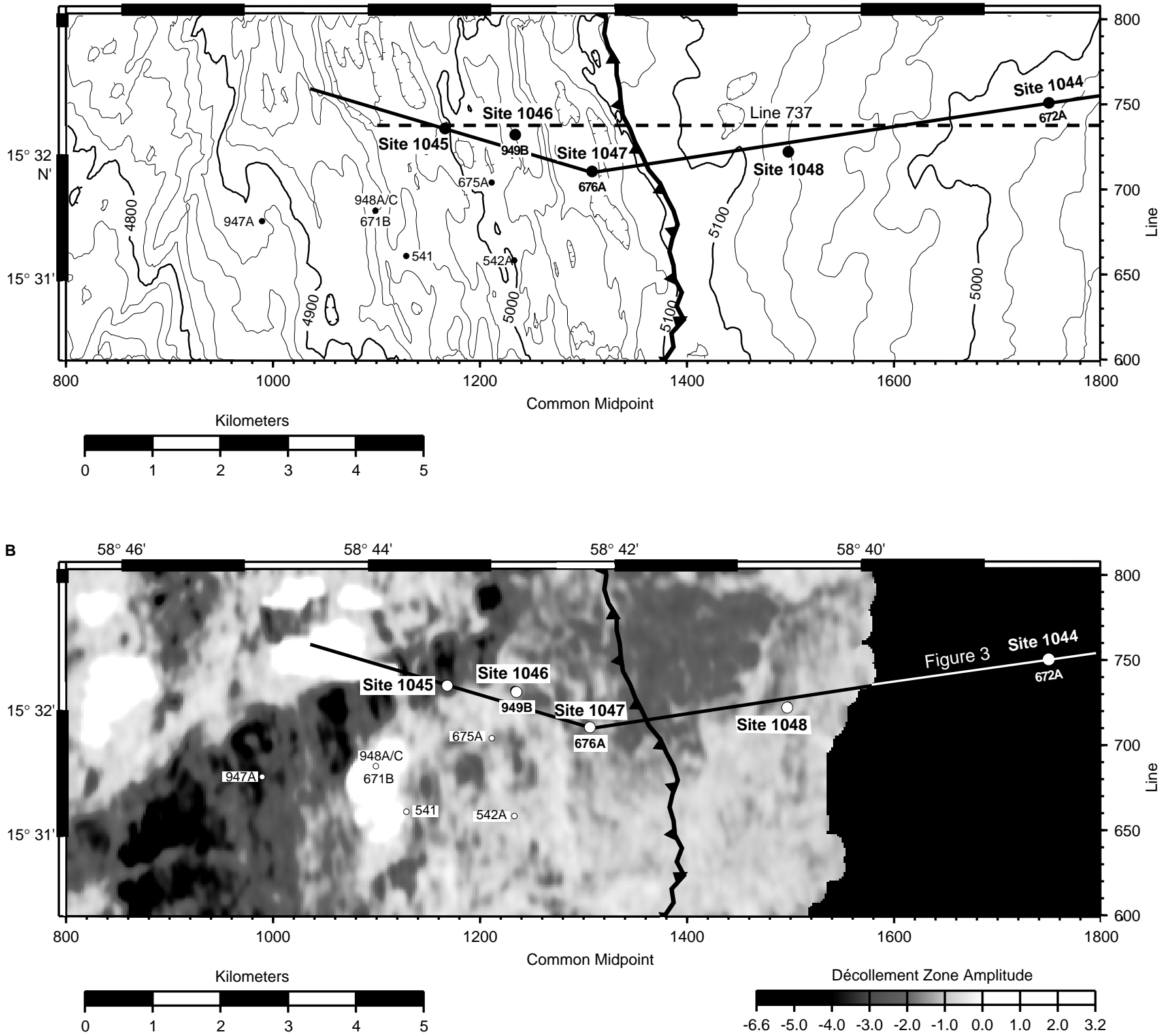

Figure 2. A. Bathymetry and location of drill sites. B. Peak seismic amplitude from the décollement zone (after Shipley et al., 1994; Moore et al., 1995a). The lines on A and B indicate the location of the seismic line in Figure 3. Dashed line indicates location of Line 737 of Figure 1 in "Site 1044" chapter, this volume. Bathymetry is derived from mapped seafloor reflections in migrated 3-D seismic records.

seismic data provide a proxy for changes in physical properties on a scale of tens of meters. Models reproduce the polarity and shape of seismic waveforms from the décollement zone beneath accretionary prisms (Bangs and Westbrook, 1991; Moore and Shipley, 1993). Accordingly, negative polarity reflections are interpreted as resulting either from overthrusting of higher impedance sediment over lower impedance sediment (Shipley et al., 1990) or the reduction of fault zone impedance through dilation (Bangs and Westbrook, 1991; Shipley et al., 1994; Bangs et al., 1996). The modeling, however, is nonunique and requires documentation of the in situ physical properties across fault zones in areas with high-quality 3-D seismic data.

The Barbados décollement zone has been logged only at one locality (Shipboard Scientific Party, 1995). These LWD data are in an area of positive reflection polarity and show impedance increases that reproduce the positive polarity in synthetic seismograms (Shipboard
Scientific Party, 1995). The LWD results also suggest the presence of thin $(0.5-1.5 \mathrm{~m})$ hydrofractures within this interval of positive impedance contrast in the décollement zone (Moore, Shipley, et al., 1995b). Major questions include whether these are true hydrofractures and, if so, whether they can be documented elsewhere, especially where negative polarity reflections occur along the décollement zone.

\section{WHY BARBADOS?}

The absence and/or failure of wireline logging operations means that hundreds of previously drilled DSDP and ODP holes provide scientifically exciting locales for LWD. Barbados is especially attractive for focused LWD investigations for the following reasons: 


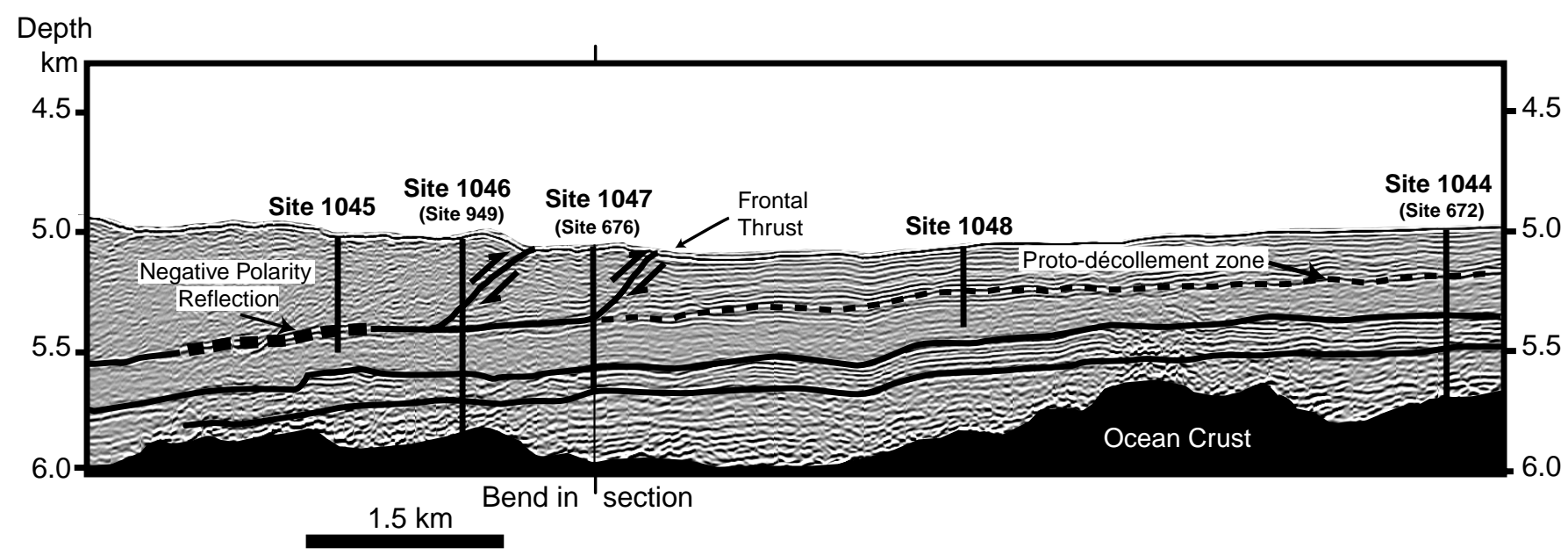

Figure 3. Cross section from the seismic depth section extending from west of Site 1045 to Site 1047 (Site 676, ODP Leg 110) and finally through Site 1044 (Site 672, ODP Leg 110). The lines below the level of the décollement and proto-décollement zones show the approximate limits of the underthrust terrigenous sequence.

1. Previous drilling at Barbados has provided high-quality structural, pore-water chemistry, heat flow, and shipboard physical properties studies. This information provides an independent determination of fault locations, fluid-flow activity, and correlative physical properties. A wealth of shipboard information and subsequent scientific results provide a rich framework for enhanced log interpretation.

2. The décollement zone occurs at depths that can be reached by drilling.

3. Barbados is one of only two convergent margins where 3-D seismic reflection surveys have been conducted. This extraordinary data set vastly expands the opportunity for core-logseismic integration and the consequent 3-D analysis of faulting, fluid flow, and consolidation.

4. Finally, the northern Barbados Ridge is an end-member accretionary prism characterized by moderately thin pelagic and hemipelagic sediment, in contrast to, for example, the Cascadia accretionary prism, which is forming from a voluminous coarse terrigenous clastic influx.

\section{DRILLING PLAN}

LWD investigations of the northern Barbados accretionary prism build on existing LWD measurements at Site 948 that penetrated the décollement zone where it is of positive polarity (Fig. 2). Although LWD was also conducted at Site 947, this locality was not cored, nor was its décollement zone reached, because of unstable hole conditions encountered during LWD penetration. Operations at the Leg $171 \mathrm{~A}$ sites were planned to begin with logging of the incoming sedimentary section at Site 1044, previously cored as Site 672 during Leg 110. The remaining sites extend westward across the deformation front and sample various stages of development of the accretionary prism, décollement zone, and reflections along the décollement zone.

\section{REFERENCES}

Bangs, N.L.B., Shipley, T.H., and Moore, G.F., 1996. Elevated fluid pressures and fault zone dilation inferred from seismic models of the northern Barbados Ridge décollement. J. Geophys. Res., 101:627-642.

Bangs, N.L.B, and Westbrook, G.K., 1991. Seismic modeling of the décollement zone at the base of the Barbados Ridge accretionary complex. $J$. Geophys. Res., 96:3853-3866.
Bangs, N.L.B., Westbrook, G.K., Ladd, J.W., and Buhl, P., 1990. Seismic velocities from the Barbados Ridge Complex: indicators of high pore fluid pressures in an accretionary complex. J. Geophys. Res., 95:87678782

Becker, K., Fisher, A.T., and Davis, E.E., 1997. The CORK experiment in Hole 949C: long-term observations of pressure and temperature in the Barbados accretionary prism. In Shipley, T.H., Ogawa, Y., Blum, P., and Bahr, J.M. (Eds.), Proc. ODP, Sci. Results, 156: College Station, TX (Ocean Drilling Program), 247-252.

Bekins, B.A., McCaffrey, A.M., and Driess, S.J., 1995. Episodic and constant flow models for the origin of low-chloride waters in a modern accretionary complex. Water Resour. Res., 31:3205-3215.

Biju-Duval, B., LeQuellec, P., Mascle, A., Renard, V., and Valery, P., 1982. Multibeam bathymetric survey and high resolution seismic investigations of the Barbados Ridge complex (Eastern Caribbean): a key to the knowledge and interpretation of an accretionary wedge. Tectonophysics, 86:275-304

Bray, C.J., and Karig, D.E., 1986. Physical properties of sediments from the Nankai Trough, Deep Sea Drilling Project Leg 87A, Sites 582 and 583. In Kagami, H., Karig, D.E., Coulbourn, W.T., et al., Init. Repts. DSDP, 87: Washington (U.S. Govt. Printing Office), 827-842.

Brown, K.M., and Behrmann, J., 1990. Genesis and evolution of small-scale structures in the toe of the Barbados Ridge accretionary wedge. In Moore, J.C., Mascle, A., et al., Proc. ODP, Sci. Results, 110: College Station, TX (Ocean Drilling Program), 229-244.

Brown, K.M., Bekins, B., Clennell, B., Dewhurst, D., and Westbrook, G., 1994. Heterogeneous hydrofracture development and accretionary fault dynamics. Geology, 22:259-262.

Brückmann, W., Moran, K., and MacKillop, A.K., 1997. Permeability and consolidation characteristics from Site 949B. In Shipley, T.H., Ogawa, Y., Blum, P., Bahr, J.M. (Eds.), Proc. ODP, Sci. Results, 156: College Station, TX (Ocean Drilling Program), 109-114.

Demets, C., Gordon, R.G., Argus, D.F., and Stein, S., 1990. Current plate motions. Geophys. J. Int., 101:425-478.

Dorel, J., 1981. Seismicity and seismic gap in the Lesser Antilles arc and earthquake hazard in Guadeloupe. Geophys. J. R. Astron. Soc., 67:679695.

Fisher, A.T., and Hounslow, M.W., 1990. Heat flow through the toe of the Barbados accretionary complex. In Moore, J.C., Mascle, A., et al., Proc. ODP, Sci. Results, 110: College Station, TX (Ocean Drilling Program), 345-363.

Fisher, A.T., Zwart, G., and Shipboard Scientific Party, 1996. The relationship between permeability and effective stress along a plate-boundary fault, Barbados accretionary complex. Geology, 24:307-310.

Gieskes, J.M., Vrolijk, P., and Blanc, G., 1990. Hydrogeochemistry of the northern Barbados accretionary complex transect: Ocean Drilling Program Leg 110. J. Geophys. Res., 95:8809-8818. 
Jordan, T.H., 1975. The present day motion of the Caribbean plate. J. Geophys. Res., 80:4433-4439.

Karig, D.E., 1986. Physical properties and mechanical state of accreted sediments in the Nankai Trough, Southwest Japan Arc. In Moore, J.C. (Ed.), Structural Fabrics in Deep Sea Drilling Project Cores from Forearcs. Mem.-Geol. Soc. Am., 66:117-133.

Kastner, M., Zheng, Y., Laier, T., Jenkins, W., and Ito, T., 1997. Geochemical of fluids and flow regime in the décollement zone at the northern Barbados Ridge. In Shipley, T.H., Ogawa, Y., Blum, P., Bahr, J.M. (Eds.), Proc. ODP, Sci. Results, 156: College Station, TX (Ocean Drilling Pro-gram), 311-320.

Labaume, P., Kastner, M., Truve, A., and Henry, P., 1997. Carbonate veins from the décollement zone at the toe of the northern Barbados accretionary prism: microstructure, mineralogy, geochemistry, and relations with prism structures and fluid regimes. In Shipley, T.H., Ogawa, Y., Blum, P., Bahr, J.M. (Eds.), Proc. ODP, Sci. Results, 156: College Station, TX (Ocean Drilling Program), 79-96.

Mascle, A., Moore, J.C., et al., 1988. Proc. ODP, Init. Repts., 110: College Station, TX (Ocean Drilling Program).

Moore, G.F., and Shipley, T.H., 1993. Character of the décollement in the Leg 131 area, Nankai Trough. In Hill, I.A., Taira, A., Firth, J.V., et al., Proc. ODP, Sci. Results, 131: College Station, TX (Ocean Drilling Program), 73-82.

Moore, G.F., Zhao, Z., Shipley, T.H., Bangs, N., and Moore, J.C., 1995a. Structural setting of the Leg 156 area, northern Barbados Ridge accretionary prism. In Shipley, T.H., Ogawa, Y., Blum, P., et al., Proc. ODP, Init. Repts., 156: College Station, TX (Ocean Drilling Program), 13-27.

Moore, J.C., Shipley, T.H., Goldberg, D., Ogawa, Y., Filice, F., Fisher, A., Jurado, M.-J., Moore G.F., Rabaute, A., Yin, H., Zwart, G., and Brückmann, W., Henry, P., Ashi, J., Blum, P., Meyer, A., Housen, B., Kastner, M., Labaume, P., Laier, T., Leitch, E.C., Maltman, A.J., Peacock, S., Steiger, T.H., Tobin, H.J., Underwood, M.B., Xu, Y., Zheng, Y., 1995b. Abnormal fluid pressures and fault zone dilation in the Barbados accretionary prism: evidence from logging while drilling. Geology, 23:605608.

Screaton, E.J., Fisher, A.J., Carson, B., and Becker, K., 1997. Barbados Ridge hydrogeologic tests: Implications for fluid migration along an active décollement. Geology, 25:239-242.

Shipboard Scientific Party, 1995. Site 948. In Shipley, T.H., Ogawa, Y., Blum, P., et al., Proc. ODP, Init. Repts., 156: College Station, TX (Ocean Drilling Program), 87-192.

Shipley, T.H., Moore, G.F., Bangs, N.L., Moore, J.C., and Stoffa, P.L., 1994. Seismically inferred dilatancy distribution, northern Barbados Ridge décollement: implications for fluid migration and fault strength. Geology, 22:411-414.
Shipley, T.H., Moore, G.F., Tobin, H., and Moore, J.C., 1997. Synthesis of the Barbados décollement seismic reflection response from drillingbased geophysical observations and physical properties. In Shipley, T.H., Ogawa, Y., Blum, P., Bahr, J.M. (Eds.), Proc. ODP, Sci. Results, 156: College Station, TX (Ocean Drilling Program), 293-302.

Shipley, T.H., Ogawa, Y., Blum, P., et al., 1995. Proc. ODP, Init. Repts., 156: College Station, TX (Ocean Drilling Program).

Shipley, T.H., Stoffa, P.L., and Dean, D.F., 1990. Underthrust sediments, fluid migration paths, and mud volcanoes associated with the accretionary wedge off Costa Rica: Middle America trench. J. Geophys. Res., 95:8743-8752.

Sykes, L.R., McCann, W.R., and Kafka, A.L., 1982. Motion of Caribbean plate during last 7 million years and implications for earlier Cenozoic movements. J. Geophys. Res., 87:10,656-10,676.

Tobin, H.J., Moore, J.C., and Moore, G.F., 1994. Fluid pressure in the frontal thrust of the Oregon accretionary prism: experimental constraints. Geology, 22:979-982.

Tobin, H.T., and Moore, J.C., 1997. Variations in ultrasonic velocity and density with pore pressure in the décollement zone, Northern Barbados Ridge accretionary prism. In Shipley, T.H., Ogawa, Y., Blum, P., Bahr, J.M. (Eds.), Proc. ODP, Sci. Results, 156: College Station, TX (Ocean Drilling Program), 125-135.

Westbrook, G.K., Ladd, J.W., Buhl, P., Bangs, N., and Tiley, G.J., 1988. Cross section of an accretionary wedge: Barbados Ridge complex. Geology, 16:631-635.

Westbrook, G.K., Mascle, A., and Biju-Duval, B., 1984. Geophysics and structure of the Lesser Antilles forearc. In Biju-Duval, B., Moore, J.C., et al., Init. Repts. DSDP, 78A: Washington (U.S. Govt. Printing Office), 2338.

Westbrook, G.K., and Smith, M.J., 1983. Long décollements and mud volcanoes: evidence from the Barbados Ridge Complex for the role of high pore-fluid pressure in the development of an accretionary complex. Geology, 11:279-283.

Zwart, G., Brückmann, W., Moran, K., MacKillop, A.K., Maltman, A.J., Bolton, A., Vrolijk, P., Miller, T., Gooch, M.J., and Fisher, A., 1997. Evaluation of hydrogeologic properties of the Barbados accretionary prism: a synthesis of Leg 156 results. In Shipley, T.H., Ogawa, Y., Blum, P., Bahr, J.M. (Eds.), Proc. ODP, Sci. Results, 156: College Station, TX (Ocean Drilling Program), 303-310.

\section{Ms 171AIR-101}



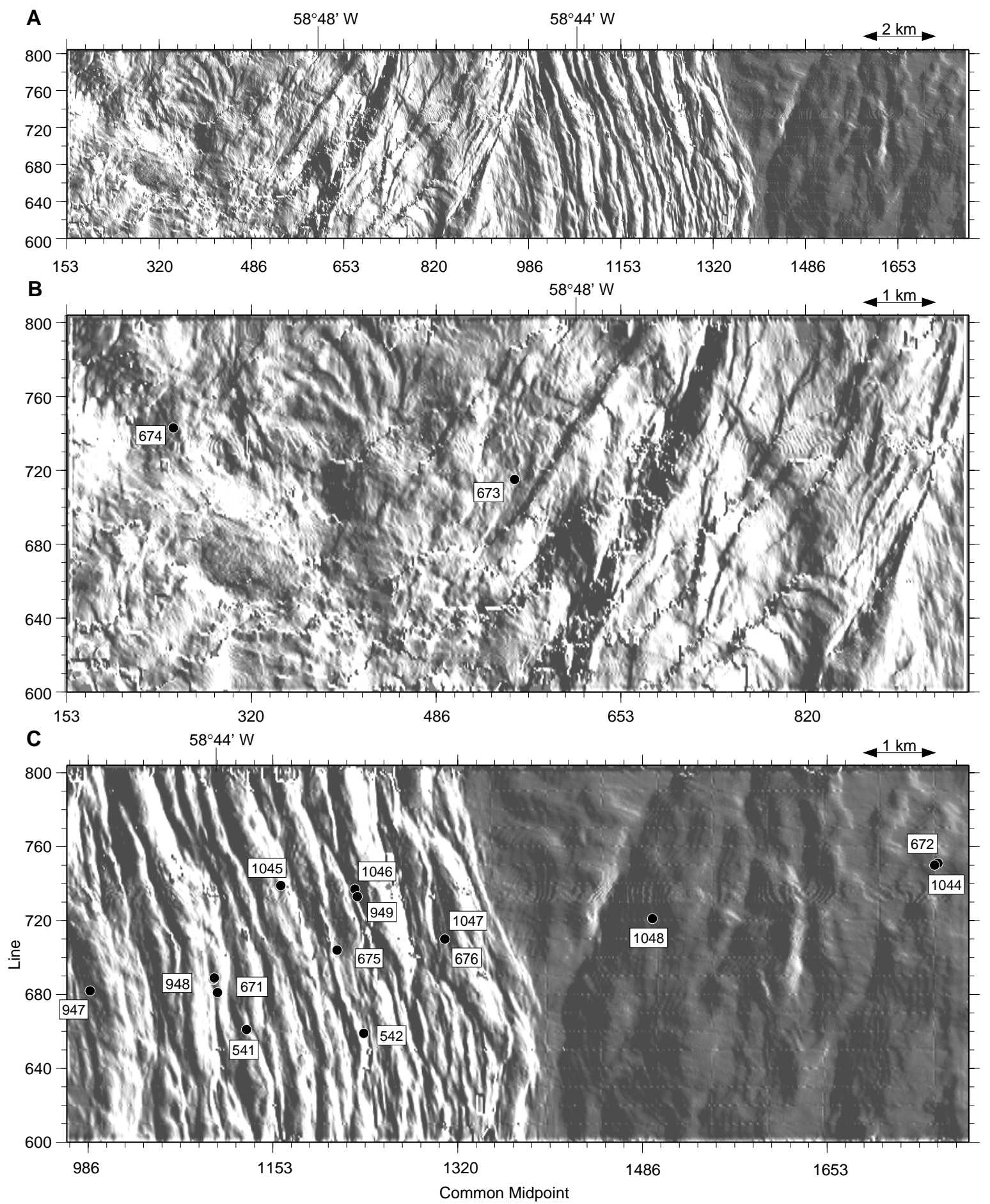

Figure 4. A. Shaded relief image of the seafloor reflection within the 3-D seismic survey area. The seismic horizon was interpreted along the zero crossing between the first negative and first positive seafloor reflections on a grid of approximately every 10th line and every 50th common midpoint. Between interpreted lines, the horizon was mapped using the Landmark Zone Autopicker algorithm, which extends horizon interpretations throughout the data set by following specified trace characteristics. The resultant horizon contains a value for every line and common midpoint of the 3 -D survey (bin spacing is $25 \mathrm{~m} \times 15 \mathrm{~m}$, respectively). Illumination is from the southeast and gray-scale shades are histogram equalized. The overall water depth increases to the east, but small-scale bathymetric variations reveal at least three distinct structural regions. Within the first region, between common midpoints 480 and 920 , a series of south-southwest-trending lineations is visible downstepping to the northwest. The second region, from common midpoints 920 to 1386, encompasses south-southeasttrending lineations related to thrusting in the toe of the prism. East of common midpoint 1386, within the third structural region, bathymetric changes are subdued, but a series of south-southwest-trending lineations is visible. These downstep to the north-northwest and are related to the topography of the underlying oceanic crust. B. Enlarged view (200\%) of the area between common midpoints 153 and 986, showing the location of Leg 110 sites. C. Enlarged view (200\%) of the area between common midpoints 986 and 1781, showing the location of the sites from Legs 110, 156, and 171A. 